Article

\title{
Chemical Composition, Antimicrobial Properties of Siparuna guianensis Essential Oil and a Molecular Docking and Dynamics Molecular Study of its Major Chemical Constituent
}

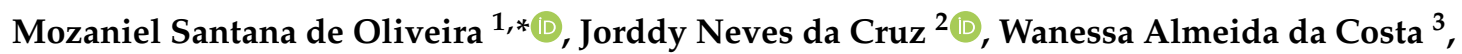 \\ Sebastião Gomes Silva ${ }^{2}{ }^{\complement}$, Mileide da Paz Brito ${ }^{4}$, Sílvio Augusto Fernandes de Menezes ${ }^{4}$, \\ Antônio Maia de Jesus Chaves Neto ${ }^{3,5}$, Eloisa Helena de Aguiar Andrade ${ }^{2,6}$ and \\ Raul Nunes de Carvalho Junior $1,3, *$ \\ 1 Program of Post-Graduation in Food Science and Technology, LABEX/FEA (Faculty of Food Engineering), \\ Federal University of Para, Rua Augusto Corrêa S/N, Guamá, Belém PA 66075-900, Brazil \\ 2 Adolpho DuckeLaboratory, Botany Coordination, Museu Paraense Emílio Goeldi, Av. Perimetral, 1900, \\ Terra Firme, Belém PA 66077-830, Brazil; jorddynevescruz@gmail.com (J.N.d.C.); \\ professebastiao@yahoo.com.br (S.G.S.); eloisandrade@ufpa.br (E.H.d.A.A.) \\ 3 Program of Post-Graduation in Natural Resources Engineering, Federal University of Para, Rua Augusto \\ Corrêa S/N, Guamá, Belém PA 66075-900, Brazil; wanessa.almeida712@yahoo.com (W.A.d.C.); \\ amchaves@ufpa.br (A.M.d.J.C.N.) \\ 4 The University Center of Pará State - Av. Governador José Malcher, 1963 - Nazaré, Belém PA 66075-900, Brazil; \\ mileidepb@yahoo.com.br (M.d.P.B.); menezesperio@gmail.com (S.A.F.d.M.) \\ 5 Laboratory of Preparation and Computation of Nanomaterials, Federal University of Para, Rua Augusto \\ Corrêa S/N, Guamá, Belém PA 66075-900, Brazil \\ 6 Program of Post-Graduation in Chemistry, Federal University of Para, Rua Augusto Corrêa S/N, Guamá, \\ Belém PA 66075-900, Brazil \\ * Correspondence: mozaniel.oliveira@yahoo.com.br (M.S.d.O.); raulncj@ufpa.br (R.N.d.C.J.); \\ Tel.: +55-91-98742-0195 (M.S.d.O.); +55-91-98864-7823 (R.N.d.C.J.)
}

Received: 29 May 2020; Accepted: 26 June 2020; Published: 25 August 2020

check for updates

\begin{abstract}
The essential oil of Siparuna guianensis was obtained by hydrodistillation. The identification of the chemical compounds was performed by gas chromatography coupled with mass spectrometry (GC/MS). Antimicrobial activity was investigated for four microorganisms: Streptococcus mutans (ATCC 3440), Enterococcus faecalis (ATCC 4083), Escherichia coli (ATCC 25922), and Candida albicans (ATCC-10231). The studies of doping and molecular dynamics were performed with the molecule that presented the highest concentration of drug-target proteins, 1IYL (C. albicans), 1C14 (E. coli), 2WE5 (E. faecalis), and 4TQX (S. mutans). The main compounds identified were: Curzerene (7.1\%), $\gamma$-Elemene (7.04\%), Germacrene D (7.61\%), trans- $\beta$-Elemenone (11.78\%), and Atractylone (18.65\%). Gram positive bacteria and fungi were the most susceptible to the effects of the essential oil. The results obtained in the simulation showed that the major compound atractylone interacts with the catalytic sites of the target proteins, forming energetically favourable systems and remaining stable during the period of molecular dynamics.
\end{abstract}

Keywords: Amazon; natural products; Capitiú; biomolecules; volatile compounds 


\section{Introduction}

Fungi and bacteria can cause various pathologies in humans. Leprosy [1], tuberculosis [2], bacterial dysentery [3], gonorrhea [4], urinary tract infection, endocarditis [5,6], onychomycosis [7], mucormycosis [8], and candidiasis [9] are examples of diseases that these microorganisms can cause. In some cases, the symbiosis between bacteria and fungi increases the virulence of bacteria, because fungi such as C. albicans elevates the production of exopolysaccharides, which can become an ideal shelter for S. mutans, thus making it difficult to control this microorganism [10]. Another important factor is the resistance that microorganisms are developing to traditional antibiotics, since this poses a threat to public health and is associated with high rates of morbidity and mortality [11]. In this sense, natural products, more specifically essential oils, can become a viable alternative for the control of fungi and bacteria $[12,13]$.

The plants that produce essential oils (EOs) have been an object of study for years, since their EOs present varied biological activities [14], such as cytotoxic, antimicrobial, antioxidant [15], anti-inflammatory, anti-proliferative [16-18], antibacterial, antifungal [19-24], antiviral [25,26], anticonvulsant [27,28], analgesic [29], and neuroprotective properties [30]. As a result, they are increasingly attracting the attention of many industry segments [31]. Essential oils consist of a complex mixture of volatile organic substances, often involving 50,100, or even more isolated components, and that contain chemical groups such as hydrocarbons, alcohols, aldehydes, ketones, acids, and esters [32].

Siparuna guianensis was the first Siparuna species described and illustrated by Aublet [33]. This plant is present from Nicaragua to Paraguay, and in Brazil, this species is known by several names, such as negramina, folha-santa, marinheiro, capitiú, mata-cachorro, catingoso, limão-bravo, cicatrizante-das-guianas, catingueira-de-paca, and fedegoso. In many countries of America, leaves of S. guianensis are widely used as a drink to combat stomach pains [34] and this activity may be related to the compounds present in its essential oil $[35,36]$. In addition, there is little research that reports on the antimicrobial activity of Siparuna guianensis essential oil, [37] including a chemotype found in Tocantins, Brazil. In this context, the objective of this work was to evaluate the chemical composition, antimicrobial activity and simulate the mechanisms of interaction of the major chemical constituent present in the essential oil of Siparuna guianensis, using doping techniques and molecular dynamics.

\section{Results and Discussion}

\subsection{Yield and Chemical Composition}

The moisture content of the S. guianensis sample was $13.58 \%$ and the volume of essential oil obtained in the hydrodistillation was $0.5 \mathrm{~mL}$, with a yield of $1.42 \%(\mathrm{db})$. Regarding the chemical profile of the essential oil of S.guianensis, 51 compounds were identified, the most important being trans- $\beta$-Elemenone $(11.78 \%)$ and Atractylone (18.65\%), followed by $\delta$-Elemene $(5.38 \%), \beta$-Elemene $(3.13 \%), \beta$ - Yerangene $(4.14 \%)$, $\gamma$-Elemene $(7.04 \%)$, Germacrene D (7.61\%), Curzerene (7.1\%), and Germacrone $(5.26 \%)$ (See Table 1$)$. In Figure 1, the ion chromatogram relative to the chemical composition can be observed. Cicció and Gómez [38] analyzed the essential oil of Siparuna thecaphora obtained by hydrodistillation and the compounds obtained in the highest concentrations were germacrene D $(32.7 \%), \alpha$-pinene $(16.3 \%)$, $\beta$-pinene $(13.8 \%)$, and e $\beta$-caryophyllene $(4.1 \%) . \quad$ In a similar study with Siparuna guianensis [39], they found myrcene (28.74\%) [40], $\beta$-myrcene (13.14\%), and the sesquiterpenes germacrene-D $(8.68 \%)$ and bicyclogermacrene $(16.71 \%)$.

In a study related to the chemical composition of S. guianensis essential oil from southeastern Brazil, they obtained high concentrations of capric acid (46.6\%) and 2-undecane (31.7\%) [41]. These compounds were not identified in other studies such as Zoghbi et al. [42], who analysed the chemical composition of S. guianensis essential oil, collected in various cities of Northern Brazil and identified epi- $\alpha$-bisabolol (25.1\%) and spathulenol (15.7\%) in Moju (PA), spathulenol $(22.0 \%)$, selin-11-en- $4 \alpha$-ol (19.4\%), $\beta$-eudesmol (10.0\%), and elemol $(10.0 \%)$ in leaves collected in Rio Branco $(\mathrm{AC})$, and germacrone $(23.2 \%)$, germacrene $\mathrm{D}(10.9 \%)$, bicyclogermacrene $(8.6 \%)$, germacrene $\mathrm{B}(8.0 \%)$ 
and atractylon (31.4\%) in Belém (PA). The results found in other studies [43-45] show that the chemical composition of the essential oil of S. guianensis varies according to the seasonality and site of collection.

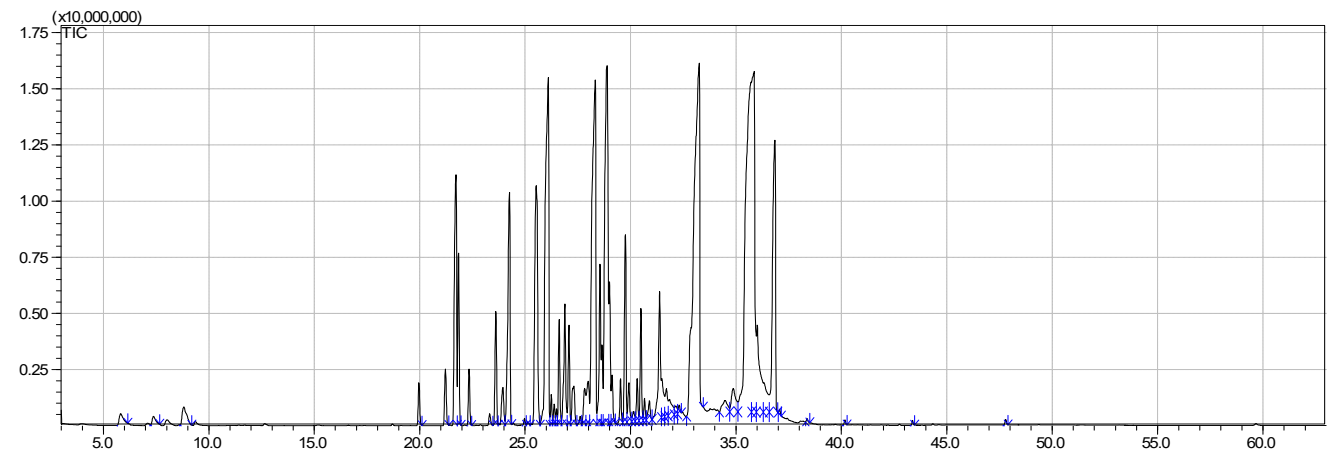

Figure 1. Ion chromatogram relative to the chemical composition S. guianensis essential oil.

Table 1. Chemical compounds identified in the essential oil of $S$. guianensis and their relative concentrations (\%).

\begin{tabular}{|c|c|c|c|c|c|}
\hline $\mathbf{R t}$ & $\mathbf{R I}_{\mathbf{C}}$ & $\mathbf{R I}_{\mathbf{L}}$ & Compound & $\begin{array}{l}\text { PubChem CID/SID } \\
\text { or Chemical Structure }\end{array}$ & Concentration $(\%)$ \\
\hline 5.817 & 933 & $932^{a}$ & $\alpha$-pinene & 6654 & 0.33 \\
\hline 7.034 & 978 & $974^{a}$ & $\beta$-pinene & 14896 & 0.04 \\
\hline 7.375 & 989 & $988^{a}$ & myrcene & 31253 & 0.22 \\
\hline 7.465 & 1008 & $1002^{a}$ & $\alpha$-phellandrene & 7460 & 0.15 \\
\hline 8.808 & 1030 & $1025^{a}$ & sylvestrene & 12304570 & 0.51 \\
\hline 8.998 & 1044 & $1044^{\mathrm{a}}$ & $(E)$ - $\beta$-ocimene & 5281553 & 0.07 \\
\hline 19.958 & 1292 & $1293^{a}$ & undecan-2-one & 8163 & 0.38 \\
\hline 21.842 & 1331 & $1335^{a}$ & $\delta$-elemene & 12309449 & 5.38 \\
\hline 22.342 & 1345 & $1345^{\mathrm{a}}$ & $\alpha$-cubebene & 86609 & 0.48 \\
\hline 23.317 & 1367 & $1373^{a}$ & $\alpha$-ylangene & 442409 & 0.12 \\
\hline 23.608 & 1373 & $1374^{\mathrm{a}}$ & $\alpha$-copaene & 442355 & 1.1 \\
\hline 23.879 & 1381 & $1387^{a}$ & $\beta$-bourbonene & 62566 & 0.52 \\
\hline 23.942 & 1383 & $1389^{a}$ & $\beta$-elemene & 6918391 & 0.55 \\
\hline 24.258 & 1386 & $1387^{a}$ & $\beta$-Cubebene & 93081 & 3.34 \\
\hline 24.654 & 1392 & $1402^{\mathrm{a}}$ & $\alpha$-funebrene & 6552024 & 0.03 \\
\hline 24.967 & 1404 & $1409^{a}$ & $\alpha$-gurjunene & 15560276 & 0.06 \\
\hline 25.158 & 1408 & $1417^{\mathrm{a}}$ & (E)-caryophyllene & 5281515 & 0.03 \\
\hline 25.525 & 1417 & $1419^{a}$ & $\beta$-ylangene & 519779 & 4.14 \\
\hline 26.1 & 1430 & $1434^{\mathrm{a}}$ & $\gamma$-elemene & 6432312 & 7.04 \\
\hline 26.242 & 1434 & $1437^{\mathrm{a}}$ & $\alpha$-guaiene & 5317844 & 0.23 \\
\hline 26.375 & 1437 & $1439^{a}$ & aromadendrene & 91354 & 0.19 \\
\hline 26.483 & 1439 & $1442^{\mathrm{a}}$ & guaia-6,9-diene & 6427475 & 0.12 \\
\hline 26.883 & 1449 & $1448^{\mathrm{a}}$ & cis-muurola-3,5-diene & 51351708 & 1.4 \\
\hline 27.075 & 1453 & 1452 & $\alpha$-humulene & 5281520 & 0.86 \\
\hline 27.408 & 1457 & $1458^{a}$ & alloaromadendrene & 10899740 & 0.29 \\
\hline 27.608 & 1459 & $1461^{\mathrm{a}}$ & cis-cadina-1(6),4-diene & 6431126 & 0.35 \\
\hline 27.788 & 1466 & $1464^{\mathrm{a}}$ & 9-epi-(E)-caryophyllene & 6429274 & 0.09 \\
\hline 27.892 & 1471 & $1475^{a}$ & $\gamma$-gurjunene & 90805 & 0.49 \\
\hline 27.925 & 1475 & $1475^{\mathrm{a}}$ & $\gamma$-muurolene & 12313020 & 0.7 \\
\hline 28.325 & 1482 & $1480^{\mathrm{a}}$ & germacrene D & 5373727 & 7.61 \\
\hline 28.55 & 1488 & $1489^{a}$ & $\beta$-selinene & 442393 & 1.61 \\
\hline 28.642 & 1490 & $1493^{a}$ & trans-muurola-4(14),5-diene & 91747125 & 0.63 \\
\hline 28.892 & 1496 & $1499^{a}$ & curzerene & 572766 & 7.1 \\
\hline 28.992 & 1498 & $1500^{a}$ & $\alpha$-muurolene & 12306047 & 1.2 \\
\hline 29.125 & 1501 & $1495^{\mathrm{a}}$ & $\gamma$-amorphene & 12313019 & 0.48 \\
\hline 29.467 & 1506 & $1508^{a}$ & germacrene A & 9548705 & 0.02 \\
\hline 29.525 & 1511 & $1513^{a}$ & $\gamma$-cadinene & 92313 & 0.39 \\
\hline 29.758 & 1516 & $1522^{a}$ & $\delta$-cadinene & 12306054 & 1.86 \\
\hline 29.925 & 1521 & $1528^{a}$ & zonarene & 6428488 & 0.48 \\
\hline 30.317 & 1530 & $1533^{a}$ & trans-cadina-1,4-diene & 91746579 & 0.45 \\
\hline
\end{tabular}


Table 1. Cont

\begin{tabular}{|c|c|c|c|c|c|}
\hline Rt & $\mathbf{R I}_{\mathbf{C}}$ & $\mathbf{R I}_{\mathbf{L}}$ & Compound & $\begin{array}{l}\text { PubChem CID/SID } \\
\text { or Chemical Structure }\end{array}$ & Concentration $(\%)$ \\
\hline 30.492 & 1534 & $1531^{b}$ & selina-4(14),7(11)-diene & 10655819 & 1.04 \\
\hline 30.667 & 1539 & $1545^{\mathrm{a}}$ & selina-3,7(11)-diene & 522296 & 0.25 \\
\hline 31.375 & 1556 & $1559^{\mathrm{a}}$ & germacrene B & 5281519 & 1.88 \\
\hline \multirow[t]{2}{*}{32.308} & 1582 & $1589^{a}$ & allo-hedycaryol & & 0.51 \\
\hline & & & & [46] & \\
\hline 32.445 & 1592 & $1589^{a}$ & cis- $\beta$-elemenone & 519762 & 1.43 \\
\hline 33.258 & 1602 & $1602^{\mathrm{a}}$ & trans- $\beta$-elemenone & & 11.78 \\
\hline 34.492 & 1633 & $1627^{\mathrm{a}}$ & cubenol<1-epi- $>$ & 91753500 & 0.97 \\
\hline 34.583 & 1643 & $1645^{\mathrm{a}}$ & cubenol & 1770062 & 1.15 \\
\hline 35.867 & 1661 & $1657^{\mathrm{a}}$ & atractylone & 3080635 & 18.65 \\
\hline 36.85 & 1694 & $1693^{a}$ & germacrone & 5317571 & 5.26 \\
\hline 38.375 & 1739 & $1740^{\mathrm{a}}$ & mint sulfide & 14564587 & 0.05 \\
\hline \multicolumn{5}{|c|}{ Monoterpene Hydrocarbons } & 1.35 \\
\hline \multicolumn{5}{|c|}{ Sesquiterpene Hydrocarbons } & 47.84 \\
\hline \multicolumn{5}{|c|}{ Oxygenated Sesquiterpenes } & 46.85 \\
\hline \multicolumn{5}{|l|}{ Others } & 0.43 \\
\hline \multicolumn{5}{|l|}{ Total } & 96.47 \\
\hline
\end{tabular}

$\mathrm{RI}_{\mathrm{C}}$ : Calculated Retention Index; $\mathrm{RI}_{\mathrm{L}}$ : Literature Retention Index. ${ }^{\mathrm{a}}$ Adams [46]; ${ }^{\mathrm{b}}$ Nist [47]; Rt: Retention time.

\subsection{Antimicrobial Activity}

The antimicrobial activity analysed by the diffusion method can be observed in Table 2 . The microorganisms presented mean inhibition halos of $11 \pm 0.12(\mathrm{~mm}), 12 \pm 0.57(\mathrm{~mm}), 11 \pm 0.31(\mathrm{~mm})$, and $12.5 \pm 0.98(\mathrm{~mm})$ for Gram-positive Streptococcus mutans (ATCC 3440), Gram-positive Enterococcus faecalis (ATCC-4083), Gram-negative Escherichia coli (ATCC 25922), and Candida albicans (ATCC-10231), respectively. Streptococcus mutans (ATCC-3440) and Candida albicans (ATCC-10231) were the most sensitive to the effects of essential oils, with a minimum inhibitory concentration of $125 \mu \mathrm{L} / \mathrm{mL}$, whereas the bacterium Enterococcus faecalis (ATCC-4083) [36] demonstrated that the essential oil of S. guianensis exerts an inhibitory effect on fungi, and on Gram-negative and Gram-positive bacteria.

Table 2. Antimicrobial activity of Siparuna guianensis leaf essential oil. Negative values (-) mean no microbial growth whereas positive values $(+)$ mean there was microbial growth under the tested concentration.

\begin{tabular}{|c|c|c|c|c|c|}
\hline \multicolumn{2}{|c|}{ Sample/ Dilution $(\mu \mathrm{L} / \mathrm{mL})$} & \multirow{2}{*}{$\begin{array}{l}\mathbf{A} \\
-\end{array}$} & \multirow{2}{*}{$\begin{array}{l}\text { B } \\
-\end{array}$} & \multirow{2}{*}{$\frac{\mathrm{C}}{\mathrm{MIC}}$} & \multirow{2}{*}{$\frac{d}{-}$} \\
\hline 1 & 500 & & & & \\
\hline 2 & 250 & - & MIC & + & - \\
\hline 3 & 125 & MIC & + & + & MIC \\
\hline 4 & 62.5 & + & + & + & + \\
\hline 5 & 30.625 & + & + & + & + \\
\hline 6 & 15.3 & + & + & + & + \\
\hline 7 & 7.6 & + & + & + & + \\
\hline 8 & 3.8 & + & + & + & + \\
\hline 9 & 1.9 & + & + & + & + \\
\hline 10 & 0.95 & + & + & + & + \\
\hline \multicolumn{2}{|c|}{ Mean halo, $10 \mu \mathrm{L}, \mathrm{N}=3$} & $11 \pm 0.12$ & $12 \pm 0.57$ & $11 \pm 0,31$ & $12.5 \pm 0,98$ \\
\hline & & $22.5 \pm 0.32$ & $28.10 \pm 0.13$ & $15.25 \pm 0.58$ & $19.42 \pm 1.22$ \\
\hline
\end{tabular}

* (A) Streptococcus mutans (ATCC 3440), (B) Enterococcus faecalis (ATCC 4083); (C) Escherichia coli (ATCC 25922);

(D) Candida albicans (ATCC- 10231). Inhibition halos (mm). 
In general, Gram-positive bacteria were the most sensitive to the effects of essential oil (EO), and this may be related to the fact that Gram-positive bacteria are more susceptible to the effects of volatile components compared to the Gram-negative ones [48]. In the case of fungi, EOs can be a viable alternative in the fight against the infection caused by Candida [24,49]. These biological effects can be related to the presence of chemically active compounds such as $\gamma$-elemene, curzerene, germacrene $D$, $\beta$-elemenone, and atractylon, as there are reports in the literature that corroborate this thesis [50-52].

\section{Interaction Mechanism}

\subsection{Molecular Binding Mode}

From our molecular docking results, it can be suggested that the ligand interacts favourably with the target proteins. In Table 3, the results of the MolDock score for each complex formed are presented.

Table 3. Docking score results.

\begin{tabular}{cc}
\hline Targets & MolDock Score \\
\hline C. albicans & -71.43 \\
E. coli & -87.24 \\
E. faecalis & -80.46 \\
S. mutans & -65.18 \\
\hline
\end{tabular}

The interactions between atractylon, the primary compound from the essential oil isolated from the leaves of Siparuna guianensis, and the catalytic site of the enzymes were analysed. The interactions that were formed are visualized in Figure 2.

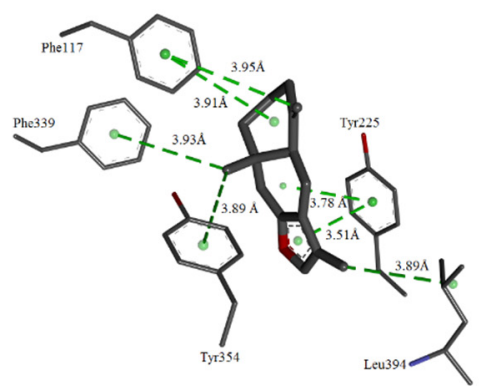

(a)

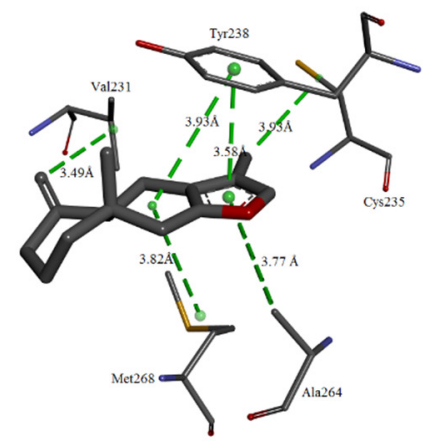

(c)

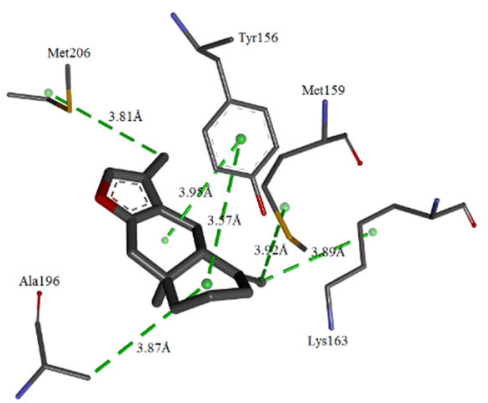

(b)

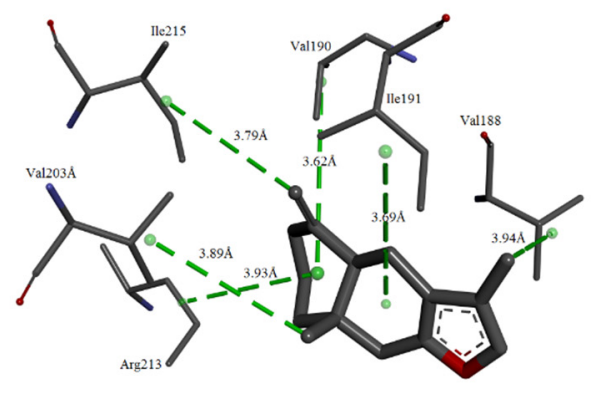

(d)

Figure 2. Molecular interactions between ligand-receptor. (a) Molecular binding of atractylon with the protein N-myristoyltransferase of the microorganism C. Albicans, (b) Molecular binding of atractylon with the protein Enoyl reductase of the microorganism E. Coli, (c) Molecular binding of atractylon with the protein Carbamate kinase of the microorganism E. faecalis, and (d) Molecular binding of atractylon with the protein Sortase A of the microorganism S. mutans. 
In Figure 2A, it is possible to observe that the ligand performed several hydrophobic interactions with different residues of the catalytic site of N-myristoyltransferase (C. albicans). With the Tyr225 residue, two interactions were established, one of the pi-pi types and the other of the pi-alkyl type. Residues Phe339 and Tyr354 had pi-alkyl-type interactions with the ligand, whereas Leu394 established alkyl interactions. Phe117 was also able to form two interactions, both of the pi-alkyl type.

With Enoyl reductase residues (E. coli), atractylon established six hydrophobic interactions. Four of these interactions were of the alkyl type with the following residues: Met206, Met159, Lys163, and Ala196. In addition, two additional pi-alkyl-type interactions with Tyr156 were formed.

The interaction of the ligand with the binding pocket of the enzyme Carbamate kinase (E. faecalis) can be seen in Figure 2C. With residues Val231, Cys235, and Met268, hydrophobic interactions of the alkyl type were formed. With Tyr238, two interactions were established, one of the pi-alkyl type and one of the pi-pi type. With Ala264, an interaction of the same type was formed.

All interactions formed with the residues of Sortase A (S. mutans) were of hydrophobic and alkyl types. These interactions were established with the following residues: Ile215, Val190, Ile191, Val188, Arg213, and Val2013.

\subsection{Analysis of Complexes Stability}

The complexes obtained by molecular docking were used as a starting point for molecular dynamics simulations. The root mean square deviation (RMSD) graphs were plotted in relation to the lowest energy structure obtained for the systems, after the execution of the protocol of energy minimization, heating, and equilibrium. To plot the RMSD of the proteins' backbone, their C $\alpha$ atoms were used and to plot the RMSD of the ligands, their heavy atoms were used. The correspondent graphs can be seen in Figure 3.
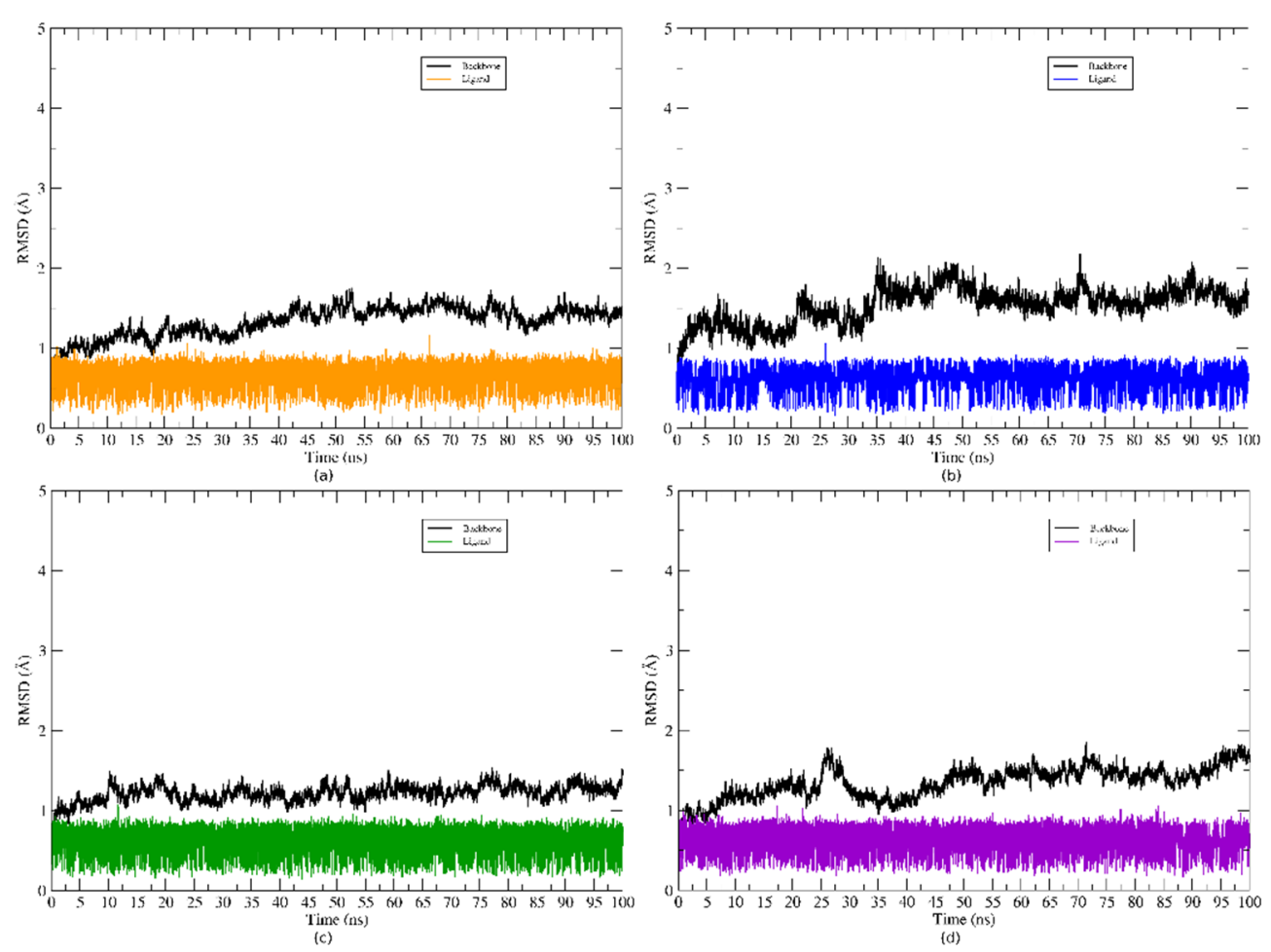

Figure 3. RMSD of systems for $100 \mathrm{~ns}$ of MD simulations. The black colour was used to colour the backbone of all proteins, whereas various colours were used for the ligand RMSD. (a) RMSD plot of the atractylon/N-myristoyltransferase system (C. albicans), (b) RMSD plot of the atractylon/Enoyl reductase system (E. coli), (c) RMSD plot of the atractylon/Carbamate kinase system (E. faecalis), and (d) RMSD plot of the atractylon/Sortase A system (S. mutans). 
For the systems formed with the target proteins of C. albicans, E. coli, E. faecalis and S. mutans, the mean RMSD obtained for the ligand was $0.65 \AA, 0.62 \AA, 0.66 \AA$, and $0.64 \AA$, respectively. Thus, it is possible to infer that during the simulations, the inhibitor remained stable at the binding site of the different targets during molecular dynamics.

The target proteins showed small conformational changes as can be observed in the RMSD plots. These changes resulted from the accommodation of the ligands at their respective binding sites.

The fluctuations observed in the RMSD for the proteins backbone may be the result of the accommodation of the ligand at the active site. The mean values for the RMSD were relatively low. These values for the backbone of the target proteins of C. albicans, E. coli, E. faecalis, and S. mutans were $1.63 \AA, 1.53 \AA$, $1.44 \AA$, and $1.65 \AA$, respectively.

\subsection{Free Energy Calculations Using MM/GBSA Approach}

For each complex, the values of affinity energy ( $\left.\triangle G_{M M-G B S A}\right)$, in addition to the values of the energetic contributions involved in the ligand-receptor interaction were obtained. The energy contributions obtained were as follows: van der Waals $\left(\Delta \mathrm{E}_{\mathrm{vdW}}\right)$, polar $\left(\Delta \mathrm{G}_{\mathrm{GB}}\right)$, non-polar $\left(\Delta \mathrm{G}_{\mathrm{NP}}\right)$, and the electrostatic interactions energies $\left(\Delta \mathrm{E}_{\text {ele }}\right)$ (Table 4$)$.

Table 4. Energy components and values of binding affinities. All values are in $\mathrm{kcal} / \mathrm{mol}$.

\begin{tabular}{cccccc}
\hline Targets & $\boldsymbol{\Delta} \mathbf{E}_{\mathbf{v d W}}$ & $\Delta \mathbf{E}_{\text {ele }}$ & $\Delta \mathbf{G}_{\mathbf{G B}}$ & $\Delta \mathbf{G}_{\mathbf{N P}}$ & $\Delta \mathbf{G}_{\mathbf{M M}-\mathbf{G B S A}}$ \\
\hline C. albicans & -22.28 & -5.51 & 13.74 & -13.11 & -25.16 \\
E. coli & -25.54 & -6.88 & 15.96 & -9.87 & -26.33 \\
E. faecalis & -19.56 & -5.02 & 8.96 & -8.22 & -23.84 \\
S. mutans & -24.35 & -3.74 & 9.75 & -9.13 & -27.47 \\
\hline
\end{tabular}

In all systems, the free energy values demonstrated that atractylon is capable of inhibiting enzymatic activity. The contributions of Van der Waals were the most responsible for the interaction of the ligand with the molecular targets. Moreover, the electrostatic and nonpolar contributions were favourable for the maintenance of the complexes.

\section{Materials and Methods}

\subsection{Preparation and Characterization of the Siparuna guianensis Sample}

The Siparuna guianensis sample was obtained in the herbarium of the Museu Paraense Emilio Goeld (Eastern Amazon), on 09/09/2016. The geographical coordinates of the collection site were S01 $27^{\prime} 04.3^{\prime \prime}$ and $\mathrm{W} 048^{\circ} 26^{\prime} 38.3^{\prime \prime}$, with a relative humidity of $64.9 \%$ and temperature of $26.5^{\circ} \mathrm{C}$. The samples were identified by Dr. Antonio Elielson Sousa da Rocha, and then, its registration number was incorporated in the Emílio Goeldi Museum Herbarium, located in the city of Belém, Pará, Brazil, under the v-oucher $M G-165435$. Before the extraction process, the sample was dried and ground and then the moisture content was determined by infrared moisture analyser. The images of the leaves of $S$. guianensis can be observed in Figure 4. 


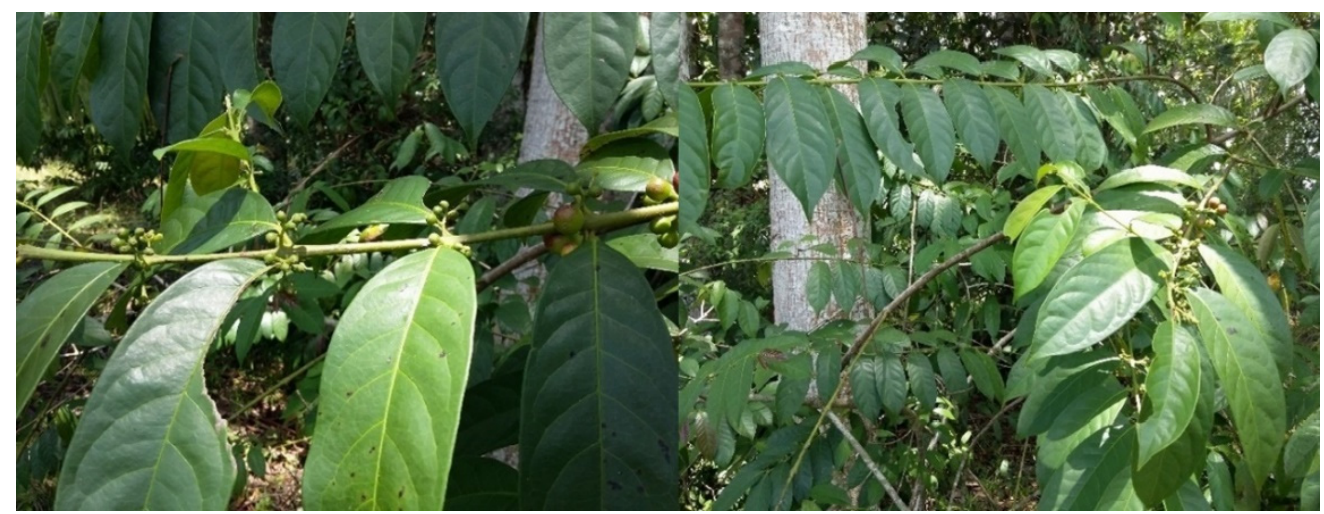

Figure 4. Leaves of Siparuna guianensis before collection.

\subsubsection{Botanical Information of the Sample}

Capitiú (Siparuna guianensis) belongs to the Siparunaceae Family. It is a shrub about three meters high, the immature fruits were greenish, and the ripe ones were greenish and purplish, with short pedunculated axillary racemes, and opposite, elliptic, and lanceolate leaves. This plant releases a characteristic odour of fish. Leaf samples were identified and deposited in the medicinal plants herbarium of the Museu Paraense Emílio Goeldi.

\subsubsection{Extraction Procedure: Hydrodistillation}

After the drying process, the leaves of S. guianensis were submitted to hydrodistillation using a Clevenger-type extractor. For the extraction process, $40 \mathrm{~g}$ of the sample was used, for $10,800 \mathrm{~s}$ at $100{ }^{\circ} \mathrm{C}$. After this procedure, anhydrous sodium sulphate $\left(\mathrm{Na}_{2} \mathrm{SO}_{4}\right)$ was added and the essential oil was centrifuged to be moisture-free. The essential oil yield was calculated in dry basis (db).

\subsection{Analysis of Volatile Compounds}

The chemical composition of the essential oils was evaluated by gas chromatography/mass spectrometry (GC/MS) according to the methodologies by $[53,54]$, using a Shimadzu QP-2010 plus system under the following conditions: silica capillary column Rtx-5MS $(30 \mathrm{~m} \times 0.25 \mathrm{~mm}, 0.25 \mu \mathrm{m}$ film thickness); program temperature of $60-240{ }^{\circ} \mathrm{C}$ at $3^{\circ} \mathrm{C} / \mathrm{min}$; injector temperature of $250^{\circ} \mathrm{C}$; helium as carrier gas (linear velocity of $32 \mathrm{~cm} / \mathrm{s}$, measured at $100^{\circ} \mathrm{C}$ ); splitless injection $(1 \mu \mathrm{L}$ of a 2:1000 hexane solution). Ionization was obtained by electronic impact technique at $70 \mathrm{eV}$, and the temperature of the ion source and other parts was set at $200^{\circ} \mathrm{C}$. The quantification of volatile compounds was determined by gas chromatography with a flame ionization detector (FID; Shimadzu, QP 2010 system-Kyoto, Japan) under the same conditions as gas chromatography coupled to mass spectrometry (GC-MS), except that hydrogen was used as the carrier gas. The retention index was calculated for all volatile constituents using a homologous series of n-alkanes $\left(\mathrm{C}_{8}-\mathrm{C}_{20}\right)$, and were identified by comparing the mass spectra obtained experimentally and their retention indices to those found in literature [46,47].

\subsection{Analysis of In vitro Antimicrobial Activity}

In the microbiological assays, standard strains of Streptococcus mutans (ATCC 3440), Enterococcus faecalis (ATCC 4083), Escherichia coli (ATCC 25922), and Candida albicans (ATCC 10231) were used. All of them were purchased from the Osvaldo Cruz Foundation (FIOCRUZ-Rio de Janeiro, Brazil), belonging to the base of standards of the Laboratory of Microbiological Quality Control of Medicines of the University Center of Pará-CESUPA.

The inoculum of each microorganism was obtained from a microbial suspension of fresh culture (maximum $24 \mathrm{~h}$ ) in saline solution $0.85 \%(\mathrm{~m} / \mathrm{V})$, by comparing the inoculum turbidity with the 
MacFarland scale, equivalent to a concentration of $1.5 \times 108 \mathrm{UFC} / \mathrm{mL}$ [55] in a turbidimeter (Grant bio, Model: DEN-1Shepreth, Cambridge, UK).

The culture medium used for the disk diffusion test was soybean casein agar (SCA) and brain Heart Infusion (BHI) broth containing $0.2 \%$ polysorbate $80(\mathrm{~m} / \mathrm{V}) .5 \%(\mathrm{v} / \mathrm{v})$ of sheep blood was added for the analysis of strains of Streptococcus mutans (ATCC 3440) and Enterococcus faecalis (ATCC 4083).

\subsection{Evaluation of the Sample Sensitivity by the Disk Diffusion Method}

Briefly, $10 \mathrm{~mL}$ of Soybean Casein Agar $(15 \times 100 \mathrm{~mm})$ was poured into a Petri dish. The microorganism $(106 \mathrm{CFU} / \mathrm{mL})$ was then inoculated with the aid of a sterile swab and paper discs $(6$ and $8 \mathrm{~m})$ impregnated with $10 \mu \mathrm{L}$ of oil. Positive and negative control were added onto the medium. The plates were incubated at $30 \pm 5{ }^{\circ} \mathrm{C} / 24 \mathrm{~h}$ in an aerobic environment $[22,55,56]$. The analysis was performed in triplicate. After the incubation period, the plates were revealed with triphenyltetrazolic chloride at $7 \mathrm{mg} / \mathrm{mL}$ in bacteriological agar at $1 \%(w / v)$. The halos were measured using a pachymeter $(\mathrm{mm})$ and evaluated by a descriptive analysis.

\subsection{Determination of Minimum Inhibitory Concentration (MIC)}

The Minimum inhibitory concentration MIC was performed with the essential oil and was adapted from the micro dilution proposed by [55]. The test was performed on an Elisa ${ }^{\circledR}$ plate, where a $100 \mu \mathrm{L}$ sample aliquot was diluted (1:2 v/v) in BHI broth containing $106 \mathrm{CFU} / \mathrm{mL}$ until 10 consecutive dilutions, and then positive and negatives controls were added. Plates were incubated at $30 \pm 5{ }^{\circ} \mathrm{C} / 48 \mathrm{~h}$. The test was performed in triplicate.

After incubation, plates were revealed with $1 \%(\mathrm{~m} / \mathrm{v})$ bacteriological broth containing $7 \mathrm{mg} / \mathrm{mL}$ triphenyltetrazolic chloride solution and incubated for further $30 \mathrm{~min}$ at $30 \pm 5^{\circ} \mathrm{C}$ for bacteria, and at $25 \pm 5^{\circ} \mathrm{C}$ for $\mathrm{C}$. albicans. The maintenance of the red colour in the medium was interpreted as microbial growth.

\subsection{Statistical Analysis}

The statistical analysis was performed using the application MiniTab17-State College, Pennsylvania, USA, using the means and their respective standard deviations.

\section{Molecular Docking and Dynamics Molecular Simulations}

\subsection{Molecular Docking}

For the study of molecular docking, atractylone was selected, since it was the primary compound from the essential oil isolated from the leaves of Siparuna guianensis. Molecular docking was used to investigate the interaction between atractylone and essential proteins of C. albicans, E. coli, E. faecalis, and S. mutans. The proteins used as a molecular target are essential for the metabolic pathways of such microorganisms, in addition to being reported in the literature as targets for natural and synthetic products that combat these pathogens [57-60].

The chemical structure of atractylon, after being designed with GaussView 5.5 software - Wallingford, Connecticut United States, was optimized with B3LYP/6-31G* [61], using Gaussian 16 (Wallingford, CT, USA) [62]. To study the interaction mode of this molecule with target-proteins for drug action, the software Molegro Virtual Docker 6 (Århus, Denmark, https://molegrovirtualdocker.weebly.com/) was used $[63,64]$. The crystal structures of the proteins used as targets can be found in the Protein Data Bank (www.rcsb.org), from their ID: 1IYL (C. albicans) [57], 1C14 (E. coli) [58], 2WE5 (E. faecalis) [59], and 4TQX (S. mutans) [60]. The MolDock Score (GRID) function was used with a Grid resolution of $0.30 \AA$ and radius of $7 \AA$, encompassing the entire crystallographic ligand binding cavity found in the PDB of each protein. The MolDock SE algorithm was used with number of runs equal to 10; 1500 max interactions, and max population size equal to 50. The maximum evaluation of 300 steps with neighbor 
distance factor equal to 1 and energy threshold equal to 100 were used during the molecular docking simulation. The RMSD limit for multiple cluster poses was set to $<1.00 \AA$.

\subsection{Molecular Dynamics (MD) Simulation}

The ligand parameters were constructed with the aid of the Antechamber module, using the General Amber Force Field (GAFF) [65]. The calculations to determine the atomic charges of the ligand were performed according to the restrained electrostatic potential (RESP) protocol using basis set Hartree-Fock level might with the functional 6-31G* [66]. To measure the protonation status of the amino acid residues of the receptors, the results obtained from the PROPKA program were used $[67,68]$.

In the molecular dynamics simulations, the force field ff14SB [69] and the explicit water molecules described by the TIP3P model [70] were used. All systems were solvated in an octahedron periodic box, where a cutting radius of $12 \AA$ was applied in all directions from the solute. Finally, in each system, an adequate number of counter-ions were added to neutralize the charge.

The MD simulations were performed with the Amber 16 package [71-73]. Sander. MPI was used for the energy minimization steps, and pmemd. CUDA, for the heating, equilibrium and MD simulations.

The energy minimization of the systems occurred in three stages. In the first step, 1500 cycles were performed using steepest descent method and conjugate gradient algorithm, applying a harmonic force constant of $100 \mathrm{kcal} / \mathrm{mol} . \AA^{-2}$ on the solute. In the second step, the harmonic force constant applied on the solute was $50 \mathrm{kcal} / \mathrm{mol} . \AA^{-2}$ and further 500 cycles were performed using the steepest descent method and conjugate gradient algorithm. In the last step, the restrictions were removed, and 500 cycles were performed using the same protocol.

To raise the systems temperature from 0 to $300 \mathrm{k}, 800 \mathrm{ps}$ of simulations were performed. The heating was carried out in three stages. In the first stage, the solute was restricted with a harmonic force constant of $50 \mathrm{kcal} / \mathrm{mol} . \AA^{-2}$. Thus, only the solvent and the counter-ions get free to move. In the next two steps, the harmonic force constant was removed.

To balance the complexes, 2 ns of simulations with constant temperature and with no restrictions were performed. Then, for each complex, $100 \mathrm{~ns}$ of MD simulation were obtained with NVT ensemble.

The particle mesh Ewald method [74] was used for the calculation of electrostatic interactions, and the bonds involving hydrogen atoms were restricted with the SHAKE algorithm [75]. The temperature control was performed with the Langevin thermostat [76] within collision frequency of $2 \mathrm{ps}^{-1}$.

\subsection{Free Energy Calculations}

The binding free energy was calculated using the molecular mechanics-generalized Born surface area (MM-GBSA) approach [77-79]. For the affinity energy calculation, 500 snapshots of the last $5 \mathrm{~ns}$ of the MD simulations trajectories were used.

The free energy was calculated according to the following equations:

$$
\Delta \mathrm{G}_{\text {bind }}=\Delta \mathrm{H}-\mathrm{T} \Delta \mathrm{S} \approx \Delta \mathrm{E}_{\mathrm{MM}}+\Delta \mathrm{G}_{\text {solv }}-\mathrm{T} \Delta \mathrm{S}
$$

where $\Delta G_{\text {bind }}$ is the free energy of the complex, which is the result of the sum of the molecular mechanics energy $\left(\Delta \mathrm{E}_{\mathrm{MM}}\right)$, the desolvation free energy $\left(\Delta \mathrm{G}_{\text {solv }}\right)$, and the entropy $(-\mathrm{T} \Delta \mathrm{S})$.

$$
\Delta \mathrm{E}_{\mathrm{MM}}=\Delta \mathrm{E}_{\text {internal }}+\Delta \mathrm{E}_{\text {electrostatic }}+\Delta \mathrm{E}_{\mathrm{vdW}}
$$

The energy of molecular gas phase mechanics $\left(\Delta \mathrm{E}_{\mathrm{MM}}\right)$ can be described by the sum of the internal energy contributions $\left(\Delta \mathrm{E}_{\text {internal }}\right)$, the sum of the connection, angle and dihedral energies, electrostatic contributions $\left(\Delta \mathrm{E}_{\text {eletrostatic }}\right)$, and van der Waals terms $\left(\Delta \mathrm{E}_{\mathrm{vdW}}\right)$.

$$
\Delta \mathrm{Gsolv}=\Delta \mathrm{G}_{\mathrm{GB}}+\Delta \mathrm{G}_{\text {nonpol }}
$$


Desolvation free energy $\left(\Delta \mathrm{G}_{\text {solv }}\right)$ is the sum of the polar $\left(\Delta \mathrm{G}_{\mathrm{GB}}\right)$ and non-polar $\left(\Delta \mathrm{G}_{\text {nonpol }}\right)$ contributions. The polar desolvation term was calculated using the implicit generalized born (GB) approaches.

\section{Conclusions}

The main compounds obtained in the essential oil of Siparuna guianensis were Atractylone (18.65\%), trans- $\beta$-Elemenone $(11.78 \%)$, Germacrene D $(7.61 \%)$, Curzerene $(7.1 \%), \gamma$-Elemene $(7.04 \%)$ and, followed by $\delta$-Elemene (5.38\%), Germacrone (5.26\%), $\beta$ - Yerangene $(4.14 \%)$, and $\beta$-Cubebene $(3.34 \%)$. The bacterium most sensitive to the effect of the essential oil was Streptococcus mutans followed by the fungus Candida albicans. Both microorganisms had the same MIC value $(125 \mu \mathrm{L} / \mathrm{mL})$. In our results, it is evidenced that atractylon interacts with all catalytic sites of the proteins and may be an inhibitor. The energy contributions observed were the electrostatic interactions energies $\left(\Delta \mathrm{E}_{\text {ele }}\right)$, and of the van der Waals $(\Delta \mathrm{EvdW})$, polar $(\Delta \mathrm{GGB})$, and nonpolar $(\Delta \mathrm{GNP})$ types.

Author Contributions: Conceptualization, M.S.d.O.; methodology and software, J.N.d.C., W.A.d.C., S.G.S.; methodology, M.d.P.B., S.A.F.d.M., A.M.d.J.C.N.; methodology and software, supervision and project administration E.H.d.A.A. and R.N.d.C.J. All authors have read and agreed to the published version of the manuscript.

Funding: This project did not have external funding.

Acknowledgments: Oliveira M. S (Process Number: 1662230) and Costa W. A. (Process Number: 1427204), thank CAPES for the doctorate scholarship and Edital 01/2020 - PAPQ - PROPESP/UFPA.

Conflicts of Interest: There is no conflict of interest in this work.

\section{References}

1. O'Brien, C.R.; Malik, R.; Globan, M.; Reppas, G.; McCowan, C.; Fyfe, J.A. Feline leprosy due to Mycobacterium lepraemurium: Further clinical and molecular characterisation of 23 previously reported cases and an additional 42 cases. J. Feline Med. Surg. 2017, 19, 737-746. [CrossRef] [PubMed]

2. Hmama, Z.; Peña-Díaz, S.; Joseph, S.; Av-Gay, Y. Immunoevasion and immunosuppression of the macrophage by Mycobacterium tuberculosis. Immunol. Rev. 2015, 264, 220-232. [CrossRef]

3. Schofield, D.A.; Wray, D.J.; Molineux, I.J. Isolation and development of bioluminescent reporter phages for bacterial dysentery. Eur. J. Clin. Microbiol. Infect. Dis. 2014, 34, 395-403. [CrossRef]

4. Fairley, C.K.; Hocking, J.S.; Zhang, L.; Chow, E.P.F. Frequent transmission of gonorrhea in men who have sex with men. Emerg. Infect. Dis. 2017, 23, 102-104. [CrossRef] [PubMed]

5. Murray, B.E. The life and times of the Enterococcus. Clin. Microbiol. Rev. 1990, 3, 46-65. [CrossRef]

6. Fasugba, O.; Gardner, A.; Mitchell, B.G.; Mnatzaganian, G. Ciprofloxacin resistance in community- and hospital-acquired Escherichia coli urinary tract infections: A systematic review and meta-analysis of observational studies. BMC Infect. Dis. 2015, 15. [CrossRef]

7. Shemer, A.; Gupta, A.K.; Amichai, B.; Baum, S.; Barzilai, A.; Farhi, R.; Kaplan, Y.; MacLeod, M.A. Increased Risk of Tinea Pedis and Onychomycosis Among Swimming Pool Employees in Netanya Area, Israel. Mycopathologia 2016, 181, 851-856. [CrossRef] [PubMed]

8. Marty, F.M.; Ostrosky-Zeichner, L.; Cornely, O.A.; Mullane, K.M.; Perfect, J.R.; Thompson, G.R.; Alangaden, G.J.; Brown, J.M.; Fredricks, D.N.; Heinz, W.J.; et al. Isavuconazole treatment for mucormycosis: A single-arm open-label trial and case-control analysis. Lancet Infect. Dis. 2016, 16, 828-837. [CrossRef]

9. Kullberg, B.J.; Arendrup, M.C. Invasive Candidiasis. N. Engl. J. Med. 2015, 373, 1445-1456. [CrossRef] [PubMed]

10. Falsetta, M.L.; Klein, M.I.; Colonne, P.M.; Scott-Anne, K.; Gregoire, S.; Pai, C.H.; Gonzalez-Begne, M.; Watson, G.; Krysan, D.J.; Bowen, W.H.; et al. Symbiotic relationship between Streptococcus mutans and Candida albicans synergizes virulence of plaque biofilms in vivo. Infect. Immun. 2014, 82, 1968-1981. [CrossRef]

11. Kaye, K.S.; Pogue, J.M. Infections Caused by Resistant Gram-Negative Bacteria: Epidemiology and Management. Pharmacotherapy 2015, 35, 949-962. [CrossRef] 
12. Łysakowska, M.E.; Sienkiewicz, M.; Banaszek, K.; Sokołowski, J.; McPhee, D.J. The sensitivity of endodontic enterococcus Spp. Strains to geranium essential oil. Molecules 2015, 20, 22881-22889. [CrossRef] [PubMed]

13. Marrufo, T.; Nazzaro, F.; Mancini, E.; Fratianni, F.; Coppola, R.; De Martino, L.; Agostinho, A.B.; De Feo, V. Chemical composition and biological activity of the essential oil from leaves of Moringa oleifera Lam. cultivated in Mozambique. Molecules 2013, 18, 10989-11000. [CrossRef] [PubMed]

14. Mandal, S.; Mandal, M. Coriander (Coriandrum sativum L.) essential oil: Chemistry and biological activity. Asian Pac. J. Trop. Biomed. 2015, 5, 421-428. [CrossRef]

15. Lai, P.; Rao, H.; Gao, Y. Chemical Composition, Cytotoxic, Antimicrobial and Antioxidant Activities of Essential oil from Anthriscus caucalis M. Bieb Grown in China. Rec. Nat. Prod. 2018, 3, 290-294. [CrossRef]

16. Bayala, B.; Bassole, I.H.N.; Gnoula, C.; Nebie, R.; Yonli, A.; Morel, L.; Figueredo, G.; Nikiema, J.B.; Lobaccaro, J.M.A.; Simpore, J. Chemical composition, antioxidant, anti-inflammatory and anti-proliferative activities of essential oils of plants from Burkina Faso. PLoS One 2014, 9, 1-11. [CrossRef]

17. Arranz, E.; Jaime, L.; López de las Hazas, M.C.; Reglero, G.; Santoyo, S. Supercritical fluid extraction as an alternative process to obtain essential oils with anti-inflammatory properties from marjoram and sweet basil. Ind. Crops Prod. 2015, 67, 121-129. [CrossRef]

18. Oliveira, M.S.d.; Almeida, M.M.; Salazar, M.d.L.A.R.; Pires, F.C.S.; Bezerra, F.W.F.; Cunha, V.M.B.; Cordeiro, R.M.; Urbina, G.R.O.; Silva, M.P.d.; Silva, A.P.S.e. Potential of Medicinal Use of Essential Oils from Aromatic Plants. In Potential of Essential Oils; Hany, A.E.-S., Ed.; InTech: Londo, UK, 2018; p. 150.

19. Zhang, H.-Y.; Gao, Y.; Lai, P.-X. Chemical Composition, Antioxidant, Antimicrobial and Cytotoxic Activities of Essential Oil from Premna microphylla Turczaninow. Molecules 2017, 22, 381. [CrossRef]

20. Mothana, R.A.; Noman, O.M.; Al-Sheddi, E.S.; Khaled, J.M.; Al-Said, M.S.; Al-Rehaily, A.J. Chemical composition, in vitro antimicrobial, free-radical-scavenging and antioxidant activities of the essential oil of Leucas inflata Benth. Molecules 2017, 22, 367. [CrossRef]

21. Diao, W.-R.; Hu, Q.-P.; Zhang, H.; Xu, J.-G. Chemical composition, antibacterial activity and mechanism of action of essential oil from seeds of fennel (Foeniculum vulgare Mill.). Food Control 2014, 35, 109-116. [CrossRef]

22. Pesavento, G.; Calonico, C.; Bilia, A.R.; Barnabei, M.; Calesini, F.; Addona, R.; Mencarelli, L.; Carmagnini, L.; Di Martino, M.C.; Lo Nostro, A. Antibacterial activity of Oregano, Rosmarinus and Thymus essential oils against Staphylococcus aureus and Listeria monocytogenes in beef meatballs. Food Control 2015, 54, 188-199. [CrossRef]

23. Da Silva Bomfim, N.; Nakassugi, L.P.; Faggion Pinheiro Oliveira, J.; Kohiyama, C.Y.; Mossini, S.A.G.; Grespan, R.; Nerilo, S.B.; Mallmann, C.A.; Alves Abreu Filho, B.; Machinski, M. Antifungal activity and inhibition of fumonisin production by Rosmarinus officinalis L. essential oil in Fusarium verticillioides (Sacc.) Nirenberg. Food Chem. 2015, 166, 330-336. [CrossRef]

24. Freires, I.D.A.; Murata, R.M.; Furletti, V.F.; Sartoratto, A.; De Alencar, S.M.; Figueira, G.M.; Rodrigues, J.A.D.O.; Duarte, M.C.T.; Rosalen, P.L. Coriandrum sativum L. (Coriander) essential oil: Antifungal activity and mode of action on Candida spp., and molecular targets affected in human whole-genome expression. PLoS ONE 2014, 9. [CrossRef] [PubMed]

25. Bektaş, E.; Daferera, D.; Sökmen, M.; Serdar, G.; Ertürk, M.; Polissiou, M.G.; Sökmen, A. In vitro antimicrobial, antioxidant, and antiviral activities of the essential oil and various extracts from thymus nummularis $\mathrm{M}$. Bieb. Indian J. Tradit. Knowl. 2016, 15, 403-410.

26. Pourghanbari, G.; Nili, H.; Moattari, A.; Mohammadi, A.; Iraji, A. Antiviral activity of the oseltamivir and Melissa officinalis L. essential oil against avian influenza A virus (H9N2). VirusDisease 2016, 27, 170-178. [CrossRef] [PubMed]

27. Masoumi-Ardakani, Y.; Mandegary, A.; Esmaeilpour, K.; Najafipour, H.; Sharififar, F.; Pakravanan, M.; Ghazvini, H. Chemical composition, anticonvulsant activity, and toxicity of essential oil and methanolic extract of Elettaria cardamomum. Planta Med. 2016, 82, 1482-1486. [CrossRef]

28. Randrianarivo, E.; Maggi, F.; Nicoletti, M.; Rasoanaivo, P. Evaluation of the anticonvulsant activity of the essential oil of Myrothamnus moschatus in convulsion induced by pentylenetetrazole and picrotoxin. Asian Pac. J. Trop. Biomed. 2016, 6, 501-505. [CrossRef]

29. Mendes, S.S.; Bomfim, R.R.; Jesus, H.C.R.; Alves, P.B.; Blank, A.F.; Estevam, C.S.; Antoniolli, A.R.; Thomazzi, S.M. Evaluation of the analgesic and anti-inflammatory effects of the essential oil of Lippia gracilis leaves. J. Ethnopharmacol. 2010, 129, 391-397. [CrossRef] 
30. Rodriguez, O.E.; Sánchez, R.M.; Verde, M.J.; Núñez, M.A.; Castro, R.; Chávez, A. Obtaining of the essential oil of Syzygium aromaticum, identification of eugenol and its effect on Streptococcus mutans. J. Oral Res. 2014, 3, 218-224. [CrossRef]

31. Zeng, Z.; Zhang, S.; Wang, H.; Piao, X. Essential oil and aromatic plants as feed additives in non-ruminant nutrition: A review. J. Anim. Sci. Biotechnol. 2015, 6. [CrossRef]

32. Salgado, A.P.S.P.; Cardoso, M.D.G.; De Souza, P.E.; De Souza, J.A.; Abreu, C.M.P.; Pinto, J.E.B.P. De Folhas De Eucalyptus SOBRE Fusarium oxysporum, Fungitoxic Activity Evaluation of Essential Leaf Oils of Eucalyptus on Fusarium oxysporum, Botrytis cinerea and Bipolaris sorokiniana. Ciênc. Agrotec. 2003, 27, 249-254. [CrossRef]

33. Renner, S.S.; Hausner, G. Siparunaceae, 1st ed.; New York Botanical Garden: New York, NY, USA, 2005.

34. Valentini, C.M.; Rodríguez-Ortíz, C.; Coelho, M.F. Siparuna guianensis Aublet (negramina): Uma revisão. Rev. Bras. Plantas Med. 2010, 12, 96-104. [CrossRef]

35. Melo, D.; Miranda, M.; Junior, W.; Alcoba, A.; Andrade, P.; Silva, T.D.S.; Cazal, C.; Martins, C. Anticariogenic and Antimycobacterial Activities of the Essential Oil of Siparuna guianensis Aublet (Siparunaceae). Orbital - Electron. J. Chem. 2017, 9. [CrossRef]

36. Andrade, M.A.; Cardoso, M.D.G.; Gomes, M.d.S.; Azeredo, C.M.O.d.; Batista, L.R.; Soares, M.J.; Rodrigues, L.M.A.; Figueiredo, A.C.S. Biological activity of the essential oils from Cinnamodendron dinisii and Siparuna guianensis. Brazilian J. Microbiol. 2015, 46, 189-194. [CrossRef] [PubMed]

37. de Souza Moura, W.; de Souza, S.R.; Campos, F.S.; Sander Rodrigues Cangussu, A.; Macedo Sobrinho Santos, E.; Silva Andrade, B.; Borges Gomes, C.H.; Fernandes Viana, K.; Haddi, K.; Oliveira, E.E.; et al. Antibacterial activity of Siparuna guianensis essential oil mediated by impairment of membrane permeability and replication of pathogenic bacteria. Ind. Crops Prod. 2020, 146, 112142. [CrossRef]

38. Issn, O. Revista de Biología Tropical. Rev. Biol. Trop. 2000, 11, 1-15.

39. de Bessa, N.G.F.; Pereira, M.E.A.B.; Ferraz, V.; Poletto, K.Q.; Junior, A.I.F.C.; Alves, A. Antimicrobial activity and medicinal biomass of Siparuna guianensis in Brazilian Cerrado forest, a global hotspot. J. Med. Plants Res. 2015, 9, 968-980. [CrossRef]

40. Andrade, M.; das Graças Cardoso, M.; de Andrade, J.; Silva, L.; Teixeira, M.; Valério Resende, J.; da Silva Figueiredo, A.; Barroso, J. Chemical Composition and Antioxidant Activity of Essential Oils from Cinnamodendron dinisii Schwacke and Siparuna guianensis Aublet. Antioxidants 2013, 2, 384-397. [CrossRef]

41. Fischer, D.C.H.; Limberger, R.P.; Henriques, A.T.; Moreno, P.R.H. Essential oils from fruits and Leaves of Siparuna guianensis (Aubl.) Tulasne from Southeastern Brazil. J. Essent. Oil Res. 2005, 17, 101-102. [CrossRef]

42. Zoghbi, M.d.G.B.; Andrade, E.H.A.; Santos, A.S.; Silva, M.H.L.; Maia, J.G.S. Essential Oils of Siparuna guianensis Aubl. J. Essent. Oil Res. 1998, 10, 543-546. [CrossRef]

43. Machado, S.M.F.; Ribeiro, V.A.F.A.; Militão, J.S.L.T.; De Morais, S.M.; Machado, M.I.L. Seasonal variation of (E)-nerolidol in siparuna guianensis aublet and13C-NMR spectral assignments of (E)- and (Z)-nerolidol. J. Essent. Oil Res. 1998, 10, 708-710. [CrossRef]

44. Viana, F.A.; Andrade-Neto, M.; Pouliquen, Y.B.M.; Uchoa, D.E.A.; Sobral, M.M.S.Z.; de Morais, S.M. Essential oil of siparuna guianensis aublet from the amazon region of Brazil. J. Essent. Oil Res. 2002, 14, 60-62. [CrossRef]

45. Andrade, E.H.A.; Zoghbi, M.G.B.; Machado, L.B. Seasonal variation of germacrone and atractylone in the essential oil of Siparuna guianensis Aublet. Rev. Bras. Plantas Med. 2004, 6, 62-64.

46. Adams, R.P. Identification of Essential Oil Components by Gas Chromatography/Mass Spectroscopy, 4th ed.; Adams, R.P., Ed.; Allured Publishing Corporation: Carol Stream, IL, USA, 28 February 2007; ISBN 1932633219.

47. Stein, S.; Mirokhin, D.; Tchekhovskoi, D.; Mallard, G.; Mikaia, A.; Zaikin, V.; Sparkmanm, D. The NIST Mass Spectral Search Program for the Nist/Epa/Nih Mass Spectra Library; Standard Reference Data Program of the National Institute of Standards and Technology: Gaithers-burg, MD, USA, 2011.

48. Smith-Palmer, A.; Stewart, J.; Fyfe, L. Antimicrobial properties of plant essential oils and essences against five important food-borne pathogens. Lett. Appl. Microbiol. 1998, 26, 118-122. [CrossRef]

49. Cavaleiro, C.; Salgueiro, L.; Gonçalves, M.J.; Hrimpeng, K.; Pinto, J.; Pinto, E. Antifungal activity of the essential oil of Angelica major against Candida, Cryptococcus, Aspergillus and dermatophyte species. J. Nat. Med. 2015, 69, 241-248. [CrossRef] 
50. Resch, M.; Steigel, A.; Chen, Z.L.; Bauer, R. 5-lipoxygenase and cyclooxygenase-1 inhibitory active compounds from Atractylodes lancea. J. Nat. Prod. 1998, 61, 347-350. [CrossRef]

51. Ogunwande, I.A.; Olawore, N.O.; Ekundayo, O.; Walker, T.M.; Schmidt, J.M.; Setzer, W.N. Studies on the essential oils composition, antibacterial and cytotoxicity of Eugenia uniflora L. Int. J. Aromather. 2005, 15, 147-152. [CrossRef]

52. Govindarajan, M.; Rajeswary, M.; Senthilmurugan, S.; Vijayan, P.; Alharbi, N.S.; Kadaikunnan, S.; Khaled, J.M.; Benelli, G. Curzerene, trans- $\beta$-elemenone, and $\gamma$-elemene as effective larvicides against Anopheles subpictus, Aedes albopictus, and Culex tritaeniorhynchus: Toxicity on non-target aquatic predators. Environ. Sci. Pollut. Res. 2018, 25, 10272-10282. [CrossRef] [PubMed]

53. Gurgel, E.S.C.; de Oliveira, M.S.; Souza, M.C.; Silva, S.G.d.; de Mendonça, M.S.; Souza Filho, A.P.d.S. Chemical compositions and herbicidal (phytotoxic) activity of essential oils of three Copaifera species (Leguminosae-Caesalpinoideae) from Amazon-Brazil. Ind. Crops Prod. 2019, 142, 111850. [CrossRef]

54. Ferreira, O.O.; da Cruz, J.N.; Franco, C.d.J.P.; Silva, S.G.; da Costa, W.A.; de Oliveira, M.S.; Andrade, E.H.d.A. First Report on Yield and Chemical Composition of Essential Oil Extracted from Myrcia eximia DC (Myrtaceae) from the Brazilian Amazon. Molecules 2020, 25, 783. [CrossRef]

55. Clinical and Laboratory Standards Institute (CLSI). Methods for Dilution Antimicrobial Susceptibility Tests for Bacteria That Grow Aerobically; Approved Standard-Seventh Edition; Clinical and Laboratory Standards Institute: Wayne, PA, USA, 2006; Volume 2, ISBN 1-56238-587-9.

56. Knezevic, P.; Aleksic, V.; Simin, N.; Svircev, E.; Petrovic, A.; Mimica-Dukic, N. Antimicrobial activity of Eucalyptus camaldulensis essential oils and their interactions with conventional antimicrobial agents against multi-drug resistant Acinetobacter baumannii. J. Ethnopharmacol. 2016, 178, 125-136. [CrossRef]

57. Sogabe, S.; Masubuchi, M.; Sakata, K.; Fukami, T.A.; Morikami, K.; Shiratori, Y.; Ebiike, H.; Kawasaki, K.; Aoki, Y.; Shimma, N.; et al. Crystal Structures of Candida albicans N-Myristoyltransferase with Two Distinct Inhibitors. Chem. Biol. 2002, 9, 1119-1128. [CrossRef]

58. Qiu, X.; Abdel-Meguid, S.S.; Janson, C.A.; Court, R.I.; Smyth, M.G.; Payne, D.J. Molecular basis for triclosan activity involves a flipping loop in the active site. Protein Sci. 2008, 8, 2529-2532. [CrossRef] [PubMed]

59. Ramón-Maiques, S.; Marina, A.; Guinot, A.; Gil-Ortiz, F.; Uriarte, M.; Fita, I.; Rubio, V. Substrate binding and catalysis in carbamate kinase ascertained by crystallographic and site-directed mutagenesis studies: Movements and significance of a unique globular subdomain of this key enzyme for fermentative ATP production in bacteria. J. Mol. Biol. 2010, 397, 1261-1275. [CrossRef] [PubMed]

60. Wallock-Richards, D.J.; Marles-Wright, J.; Clarke, D.J.; Maitra, A.; Dodds, M.; Hanley, B.; Campopiano, D.J. Molecular basis of Streptococcus mutans sortase A inhibition by the flavonoid natural product trans-chalcone. Chem. Commun. 2015, 51, 10483-10485. [CrossRef] [PubMed]

61. Becke, A.D. Density-functional thermochemistry. III. The role of exact exchange. J. Chem. Phys. 1993, 98, 5648-5652. [CrossRef]

62. Frisch, M.J.; Trucks, G.W.; Schlegel, H.B.; Scuseria, G.E.; Robb, M.A.; Cheeseman, J.R.; Scalmani, G.; Barone, V.; Petersson, G.A.; Nakatsuji, H.; et al. Gaussian 16 Revision 16.A.03; Wallingford CT. Inc.: Wallingford CT, UK, 2016.

63. Thomsen, R.; Christensen, M.H. MolDock: A new technique for high accuracy molecular docking. J. Med. Chem. 2006, 49, 3315-3321. [CrossRef]

64. Vale, V.V.; Cruz, J.N.; Viana, G.M.R.; Póvoa, M.M.; Brasil, D.d.S.B.; Dolabela, M.F. Naphthoquinones isolated from Eleutherine plicata herb: In vitro antimalarial activity and molecular modeling to investigate their binding modes. Med. Chem. Res. 2020, 29, 487-494. [CrossRef]

65. Wang, J.; Wolf, R.M.; Caldwell, J.W.; Kollman, P.A.; Case, D.A. Development and testing of a general amber force field. J. Comput. Chem. 2004, 25, 1157-1174. [CrossRef]

66. Cornell, W.D.; Cieplak, P.; Bayly, C.I.; Kollman, P.A. Application of RESP Charges to Calculate Conformational Energies, Hydrogen Bond Energies, and Free Energies of Solvation. J. Am. Chem. Soc. 1993, 115, 9620-9631. [CrossRef]

67. Dolinsky, T.J.; Nielsen, J.E.; McCammon, J.A.; Baker, N.A. PDB2PQR: An automated pipeline for the setup of Poisson-Boltzmann electrostatics calculations. Nucleic Acids Res. 2004, 32, 665-667. [CrossRef] [PubMed]

68. Li, H.; Robertson, A.D.; Jensen, J.H. Very fast empirical prediction and rationalization of protein $\mathrm{pK}$ a values. Proteins Struct. Funct. Genet. 2005, 61, 704-721. [CrossRef] [PubMed] 
69. Maier, J.A.; Martinez, C.; Kasavajhala, K.; Wickstrom, L.; Hauser, K.E.; Simmerling, C. ff14SB: Improving the Accuracy of Protein Side Chain and Backbone Parameters from ff99SB. J. Chem. Theory Comput. 2015, 11, 3696-3713. [CrossRef] [PubMed]

70. Jorgensen, W.L.; Chandrasekhar, J.; Madura, J.D.; Impey, R.W.; Klein, M.L. Comparison of simple potential functions for simulating liquid water. J. Chem. Phys. 1983, 79, 926-935. [CrossRef]

71. Case, D.A.; Cheatham, T.E.; Darden, T.; Gohlke, H.; Luo, R.; Merz, K.M.; Onufriev, A.; Simmerling, C.; Wang, B.; Woods, R.J. The Amber biomolecular simulation programs. J. Comput. Chem. 2005, 26, 1668-1688. [CrossRef]

72. Silva, S.G.; da Costa, R.A.; de Oliveira, M.S.; da Cruz, J.N.; Figueiredo, P.L.B.; Brasil, D.d.S.B.; Nascimento, L.D.; Chaves Neto, A.M.d.J.; de Carvalho Junior, R.N.; Andrade, E.H.d.A. Chemical profile of Lippia thymoides, evaluation of the acetylcholinesterase inhibitory activity of its essential oil, and molecular docking and molecular dynamics simulations. PLoS ONE 2019, 14, e0213393. [CrossRef]

73. de Oliveira, M.S.; da Cruz, J.N.; Gomes Silva, S.; da Costa, W.A.; de Sousa, S.H.B.; Bezerra, F.W.F.; Teixeira, E.; da Silva, N.J.N.; de Aguiar Andrade, E.H.; de Jesus Chaves Neto, A.M.; et al. Phytochemical profile, antioxidant activity, inhibition of acetylcholinesterase and interaction mechanism of the major components of the Piper divaricatum essential oil obtained by supercritical $\mathrm{CO}_{2}$. J. Supercrit. Fluids 2019, 145, 74-84. [CrossRef]

74. Darden, T.; York, D.; Pedersen, L. Particle mesh Ewald: An N·log(N) method for Ewald sums in large systems. J. Chem. Phys. 1993, 98, 10089-10092. [CrossRef]

75. Ryckaert, J.P.; Ciccotti, G.; Berendsen, H.J.C. Numerical integration of the cartesian equations of motion of a system with constraints: Molecular dynamics of n-alkanes. J. Comput. Phys. 1977, 23, 327-341. [CrossRef]

76. Lzaguirre, J.A.; Catarello, D.P.; Wozniak, J.M.; Skeel, R.D. Langevin stabilization of molecular dynamics. J. Chem. Phys. 2001, 114, 2090-2098. [CrossRef]

77. Cruz, J.N.; Costa, J.F.S.; Khayat, A.S.; Kuca, K.; Barros, C.A.L.; Neto, A.M.J.C. Molecular dynamics simulation and binding free energy studies of novel leads belonging to the benzofuran class inhibitors of Mycobacterium tuberculosis Polyketide Synthase 13. J. Biomol. Struct. Dyn. 2019, 37, 1616-1627. [CrossRef] [PubMed]

78. Ramos, R.S.; Macêdo, W.J.C.; Costa, J.S.; da Silva, C.H.; Rosa, J.M.C.; da Cruz, J.N.; de Oliveira, M.S.; de Aguiar Andrade, E.H.; e Silva, R.B.L.; Souto, R.N.P.; et al. Potential inhibitors of the enzyme acetylcholinesterase and juvenile hormone with insecticidal activity: Study of the binding mode via docking and molecular dynamics simulations. J. Biomol. Struct. Dyn. 2019, 1-23. [CrossRef] [PubMed]

79. Neves Cruz, J.; Santana de Oliveira, M.; Gomes Silva, S.; Pedro da Silva Souza Filho, A.; Santiago Pereira, D.; Lima e Lima, A.H.; de Aguiar Andrade, E.H. Insight into the Interaction Mechanism of Nicotine, NNK, and NNN with Cytochrome P450 2A13 Based on Molecular Dynamics Simulation. J. Chem. Inf. Model. 2020, 60, 766-776. [CrossRef] [PubMed]

Sample Availability: Samples of the compounds (essential oil extracted from Siparuna guianensis Aublet) are available from the authors.

(C) 2020 by the authors. Licensee MDPI, Basel, Switzerland. This article is an open access article distributed under the terms and conditions of the Creative Commons Attribution (CC BY) license (http://creativecommons.org/licenses/by/4.0/). 